\title{
Regional Science: Evolving in New Directions
}

\author{
John Rees*
}

\begin{abstract}
This paper introduces a collection of short essays on "New Directions in Regional Science" based on commentaries delivered at the 37th annual meeting of the Southern Regional Science Association in Savannah, Georgia, 1998. In response to the idea of crisis in earlier reviews of regional science, I also suggest that ongoing methodological debates in geography and economics provide many opportunities for regional science in the future. Others are optimistic about an applied regional science.
\end{abstract}

The 1990s have been a decade of reflection for regional science as members of our community have pondered the past and anticipated the future. This seems an appropriate endeavor as we approach the fin de millennium and prepare to celebrate the 50th anniversary of the Regional Science Association in 2004, as well as the 40th anniversary of the Southern Regional Science Association (SRSA) in 2001. The 37th meeting of the SRSA in the quintessential southern city of Savannah, Georgia, gave us the opportunity to reflect on "New Directions in Regional Science" and provided the basis for this collection of essays.

This southern location is equally appropriate because much of the intellectual soul searching that has taken place was started by Andy Isserman's 1992 presidential address to the SRSA in Charleston, South Carolina, and published in this journal (Isserman 1993). The evolution of this self-examination was quickly followed by Bailly and Coffey's (1994) concern that regional science may be in a state of crisis and no less than thirty-two perspectives on a possible midlife crisis for our discipline in the International Regional Science Review (1995). While many of these contributions did reflect a pessimistic concern for the future, our sessions in Savannah focused more on the potential that regional science still offers as an intellectual force and as a practical endeavor.

The Schumpeterians among us will interpret this as an intellectual process of creative destruction where the winds of intellectual and societal change contain the seeds of much creativity and optimism. In Savannah we were more than literally close to John Berendt's "garden of good and evil," and goodness prevailed (Berendt 1994). Rumors of the demise of regional science were seen to be completely premature.

This collection of essays reflects the viewpoints of an eclectic mix of individuals, but the mix is not that different from the structure of regional science as a whole. They include six geographers and two economists (not purposefully skewed); two past presidents of SRSA; one SRSA Fellow; two executive directors of the Western Regional Science Association (WRSA), another group that has

*Professor, Department of Geography, University of North Carolina at Greensboro. 
played a strong grassroots role in this general intellectual debate; and one former president of Regional Science Association International (RSAI). Unfortunately (again?), the group includes only one female, and no minorities except the two of us who are foreign born.

Before moving on to the other essays, I will take this opportunity to share my own initial concerns about the future of regional science and discuss how they become outnumbered by the opportunities afforded us by the evolving methodological debates in our two core disciplines: economics and geography (see Rees 1999). My own field of geography has been characterized as an eclectic combination of subjects and approaches without a clear intellectual core. In his presidential address to SRSA, Andy Isserman stated that: "Geography appears fickle, faddish and belligerent. The quantitative geographers of the 1960s, the Marxist geographers of the 1970s and the postmodern theorists of the 1980s are often the same people. One reaction is to admire the intellectual flexibility and dedication of geography... another is to shake one's head upon learning that the neighbor has a fifth spouse and has joined yet another cult" (Isserman 1993, p. 32). The major methodological debate in geography for the past quarter century can be summed up as locational analysis versus social theory and postmodernism. Logical positivism and locational analysis came under increasing attack from other epistemologies during the 1970s and 1980s, including Marxism, humanism, realism, and postmodernism, in what Sheppard (1995) called "a dissent from spatial analysis." While this shift away from spatial analysis to social theory has not found much support in regional science, it is the implication of postmodernism that is my main concern: a faulty tower among our ivory towers.

Postmodernism can be viewed as a deliberate attack on the epistemology of science, and has its philosophical roots in "anything goes" (Feyerabend 1975). As an approach to knowledge, it is both antitheory and antiscience. "What is in question in certain quarters of both economics and economic geography is not simply which theory but the very idea of theory itself" (Martin 1994, p. 27). The implications of postmodernism for regional science would be to throw out all the theories and methods of locational analysis as accumulated over the past half century. But regional science is not ready to be redefined as regional fiction. While methodological diversity is a worthy goal in geography and regional science, the postmodern turn may now have reached a point of diminishing returns. The pendulum has started to swing back towards an enlightened social science and what has been hailed in geography as a "second quantitative revolution" (Batty and Cole 1997). For most regional scientists, postmodernism will only amount to an intellectual cul de sac.

The study of economics, in contrast to geography, appears more as a fortress, perhaps a religious imperium, which does not allow much discussion of alternative methodologies. Economists steered clear of what they called "the saloons of sociology" at least until the 1980 s when considerably more interest was generated in questions of economic methodology (Blaug 1980; Caldwell 1982; 
McCloskey 1986). Blaug's (1980) contribution was essential because it carefully examined Kuhn's notion of scientific revolutions, Feyerabend's (1975) anarchism (previously defined as pivotal to postmodernism) and Popper's ideas on falsification, leading Caldwell (1982) to argue for a "methodological pluralism" in economics. More recently, a small but growing number of economists have become interested in another approach: the sociology of scientific knowledge (SSK). They see any such knowledge as socially constructed, but contributions to date have been limited to speculation. In geography, Barnes (1996) saw the absence of the SSK school as a major flaw and took on the highly ambitious task of trying to rewrite the history of economic geography and regional science through the tinted lenses of SSK.

These recent methodological debates in economics reveal a small but growing community of scholars who have questioned the validity of their past approaches more than other social scientists might admit. To date, such debates may not have spilled over into regional science as much as they should. In addition, the intensity of work in a variety of economic subfields has also increased since 1980, especially in the Austrian School, post-Keynesian School, and Evolutionary Economics. And where does this increasing diversity leave us as regional scientists? Caldwell's (1982) case for "methodological pluralism" in economics seems equally applicable to regional science. Some of the essays in this collection also argue for broader approaches in regional science as does Walter Isard's (1999) most recent "walk on the wild side," where he invites us to think about additional approaches from physics and chemistry.

In his perspective on "New Directions in Regional Science" in this collection, Ed Malecki echoes my concern for a broader methodology and makes a case for analyzing "the softer variables of regional science," especially local knowledge and networks, social capital, and institutional embeddedness. The concept of social capital is getting increasing attention in the social sciences as a different but related concept to human capital (Putnam 1993; Fukuyama 1995). Human capital is seen as an individual attribute related to skill, expertise, and educational achievement; and social capital is seen as a collective attribute related to trust, values, and networks as features of the social life of a community. Social capital is an important but missing ingredient in regional science to date.

Mark Henry looks at the future of regional science from his perspective in agricultural and applied economics. He focuses on the tension between theory and practice in regional science and examines what's obvious, what's wrong, and why this debate has been with us since the inception of regional science. Charley Leven revisits a topic close to the heart of many regional scientists, the economic base multiplier, and its continuing relevance to regional policy analysis.

One of our friends from the WRSA, David Plane, looks at the role of regional science in migration and population research and the opportunities for regional scientists in the growing field of applied demography. Kavita Pandit uses examples from demography and sectoral shifts among primary, secondary, and 
tertiary industries to show how Third World experiences can enrich our future as regional scientists, and how our western models are not always applicable to understanding some of the neglected regions in the Third World.

Harry Campbell returns to the topic of a more policy-relevant agenda for regional science by looking at issues of education, training, and regional development. Lay Gibson, another friend from WRSA, echoes this theme and argues the case why we as regional scientists need to "think bigger," especially by reaching out to nonuniversity-based regional researchers.

This theme of reaching out to practitioners through a more applied regional science runs through most of these commentaries on what our future should include. To many members of SRSA, this will cause a sense of déjà vu (again?), since southern regional science has always included a strong applied tradition under the dominant influence of agricultural and applied economists, the USDA and BEA at the federal level, and some input from planners and applied geographers. In his presidential address to SRSA, Jim Hite (1985) reminded us that "Southern regionalists felt an almost patriotically compelling need to devote their scholarship to finding remedies for the South's problems....Any focus on theory was subordinated to the pragmatic need to find solutions for real and pressing social problems."

This does not just make a case for "Back to the Future." It means that southern regional science reflects its southern heritage and southern context possibly more than other associations reflect their locational context (Miller 1996). Given the importance of applied regional science in the future of regional science as a whole, it shows that the SRSA has an excellent foundation on which to grow and to reach out into the future. To use Mark Henry's comment, "don't worry, be happy." The future of regional science is full of opportunities. Those of us who were pessimistic about regional science a decade ago may have paid too much attention to the first line of Shakespeare's Richard III and not enough to the second:

"Now is the winter of our discontent, Made glorious summer by this Son of York."

\section{REFERENCES}

Bailly, A.S., and W.J. Coffey. "Regional Science in Crisis: A Plea for a More Open and Relevant Approach." Papers in Regional Science 73 (1994), 3-14.

Barnes, T. Logic of Dislocation: Models, Metaphors and Meanings of Economic Space. New York: Guilford Press, 1996.

Batty, M., and S. Cole, "Time and Space: Geographic Perspectives on the Future." Futures 19 (1997), 277-289.

Berendt, John. Midnight in the Garden of Good and Evil. New York: Random House, 1994.

Blaug, M. The Methodology of Economics: Or How Economists Explain. Cambridge, MA: Cambridge University Press, 1980. 
Caldwell, B.J. Beyond Positivism: Economic Methodology in the Twentieth Century. New York: Routledge, 1982.

Fukuyama, F. Trust: The Social Virtues and the Creation of Prosperity. New York: Free Press, 1995.

Hite, J.C. "The Southern Contribution to Regional Science." The Review of Regional Studies 15 (1985), 1-18.

Isard, W. "Regional Science: Parallels from Physics and Chemistry." Papers in Regional Science 78 (1999), 5-20.

Isserman, A.M. "Lost in Space? On the History, Status and Future of Regional Science." The Review of Regional Studies 23 (1993), 1-50.

Martin, R. "Economic Theory and Human Geography." In D. Gregory, R. Martin, and D. Smith (eds.) Human Geography: Society, Space and Social Science, 21-53. London: Macmillan, 1994.

McCloskey, D.N. The Writing of Economics. New York: Macmillan, 1986.

Miller, J.R. "What is Western About Regional Science." The Annals of Regional Science 30 (1996), 343-350.

Putman, R. Making Democracy Work. Princeton, NJ: Princeton University Press, 1993.

Rees, J. "Regional Science: From Crisis to Opportunity." Papers in Regional Science 78 (1999), 101-110.

Sheppard, E. "Dissenting from Spatial Analysis." Urban Geography 16 (1995), 283-303. 
